NBER WORKING PAPER SERIES

\title{
DIRECT DEMOCRACY AND LOCAL PUBLIC GOODS: EVIDENCE FROM A FIELD EXPERIMENT IN INDONESIA
}

\author{
Benjamin A. Olken \\ Working Paper 14123 \\ http://www.nber.org/papers/w14123

\begin{abstract}
NATIONAL BUREAU OF ECONOMIC RESEARCH
1050 Massachusetts Avenue

Cambridge, MA 02138
\end{abstract} \\ June 2008
}

I thank Daron Acemoglu, Esther Duflo, Amy Finkelstein, Don Green, Michael Kremer, Katerina Linos, and David Nickerson for helpful comments. Melissa Dell provided exceptional research assistance. Special thanks are due to Susan Wong and Scott Guggenheim for their support and assistance throughout the project. The field work and engineering survey would have been impossible without the dedication of Suroso Yoso Oetomo and the SSK-PPK field staff. This project was supported by a grant from the Indonesian Decentralization Support Facility, with support from DfID and the World Bank. All views expressed are those of the author, and do not necessarily reflect the opinions of DSF, DfID, the World Bank, or the National Bureau of Economic Research.

NBER working papers are circulated for discussion and comment purposes. They have not been peerreviewed or been subject to the review by the NBER Board of Directors that accompanies official NBER publications.

(C) 2008 by Benjamin A. Olken. All rights reserved. Short sections of text, not to exceed two paragraphs, may be quoted without explicit permission provided that full credit, including $\bigcirc$ notice, is given to the source. 
Direct Democracy and Local Public Goods: Evidence from a Field Experiment in Indonesia Benjamin A. Olken

NBER Working Paper No. 14123

June 2008

JEL No. D72

\begin{abstract}
$\underline{\text { ABSTRACT }}$
This paper presents an experiment where 48 Indonesian villages were randomly assigned to choose development projects through either representative-based meetings or direct election-based plebiscites. Plebiscites resulted in dramatically higher satisfaction among villagers, increased knowledge about the project, greater perceived benefits, and higher reported willingness to contribute. Changing the political mechanism had much smaller effects on the actual projects selected, with some evidence that plebiscites resulted in projects chosen by women being located in poorer areas. The results show that direct participation in political decision making can substantially increase satisfaction and legitimacy, even when it has little effect on actual decisions.
\end{abstract}

Benjamin A. Olken

Harvard Society of Fellows

78 Mt. Auburn St.

Cambridge, MA 02138

and NBER

bolken@nber.org 


\section{Introduction}

Recent years have witnessed a trend in the developing world towards local participation in government decision making (Stiglitz 2002; World Bank 2004). What this trend means in practice is that decisions about local public good provision are increasingly delegated to local assemblies, such as the Gram Panchayat in India and the Conselho do Orçamento Participativo in Brazil. Though these forums provide for local input, only a small fraction of the population typically attends, leading to concerns that they may be prone to capture by local elites (Bardhan 2002; Bardhan and Mookherjee 2006).

This paper investigates an alternative political mechanism for deciding on local pubic goods: plebiscites, where citizens vote directly at an election for their most preferred projects. Proponents of direct democracy argue that it has two main virtues (Matsusaka 2004). First, direct democracy allows voters a way to circumvent representative institutions that may have been captured by elites or other special interests. Second, compared with meetings, elections allow an order of magnitude more citizens to participate directly in political decision making, and this increased participation may enhance the legitimacy of political decisions even if the decisions themselves do not change (Lind and Tyler 1988).

To investigate these two hypotheses, I conducted a randomized, controlled field experiment in 48 Indonesian villages, each of which were preparing to apply for infrastructure projects as part of the Indonesian Kecamatan Development Program (KDP). Under KDP, each village follows a political process that results in two proposed infrastructure proposals, one “general project” proposed by the village at large and one “women’s project” project proposed exclusively by women in the village. The experiment randomly allocated villages to choose their projects either through a standard KDP decision making process, in which projects are selected 
at representative village meetings, or through direct plebiscites, in which all villagers can vote directly at an election for their most preferred projects. To mirror the meeting-based process, in plebiscite villages two simultaneous votes were held, one in which all adults in the village were eligible to vote for the general proposal and one in which all adult women in the village were eligible to vote on the women's-specific proposal. The list of potential projects to be considered by the meeting process or by the plebiscite process was generated using an identical agendasetting process in both types of villages.

In almost all naturally-occurring settings, political decision rules are chosen endogenously through a complex political process, which makes evaluating the impact of political rules challenging (Green and Shapiro 1994). In this case, however, the fact that political mechanisms were randomly assigned allows me to evaluate their impact by simply comparing outcomes across the two experimental conditions. In so doing, I build on a small-but-growing number of randomized field experiments conducted to investigate political issues (e.g., Eldersveld 1956; Gerber and Green 2000; Wantchekon 2003; Chattopadhyay and Duflo 2004; Druckman et al. 2006). To the best of my knowledge, however, the field experiment reported here represents the first time the political process itself has ever been randomly assigned.

Using this methodology, I examine the impact of moving from meetings to plebiscites along two main dimensions. First, I examine the impact on elite capture by examining whether the types of projects chosen move closer to the preferences of villages elites and whether the location of projects move towards wealthier parts of the villages. Second, I examine the impact on legitimacy by examining a wide range of measures of villagers' satisfaction with, and perceived fairness of, the KDP program. 
First, with regard to potential elite capture of the selected project, I find relatively little impact of the plebiscite treatment on the general project, but substantial impacts on the women's project. For the general project, the type of project selected (i.e., road, irrigation system, water/sanitation, etc) did not change whatsoever as a result of the plebiscite, and there were only minor changes in the locations of these projects as a result of the plebiscite. For the women's project, by contrast, the plebiscite resulted in projects located in poorer areas of the village, which seems to suggest that the plebiscite shifted power towards poorer women who may have been disenfranchised in a more potentially elite-dominated meeting process. At the same time, however, the plebiscite resulted in the types of projects being chosen for the women's project closer to the stated preferences of the village elites. One potential explanation for these seemingly contradictory changes is, in the experimental design, the plebiscite treatment did not affect how each area of the village selected its proposals, and elites were more dominant in the agenda-setting process in poorer areas of the village. A shift in power towards poorer areas of the village at the final decision-making stage might therefore result in projects that look closer to elite preferences.

Second, with regard to measures of legitimacy and satisfaction, I find that the electionbased plebiscite process resulted in substantially higher citizen satisfaction across a wide variety of measures. For example, plebiscites substantially increased villagers' overall satisfaction with the KDP program. They also improved villagers' perceptions of the fairness and legitimacy of the selected project, and dramatically improved their stated satisfaction with the project selected. Remarkably, these findings even hold for the general project, where the type of project selected did not change at all, which suggests that these results are driven by increased legitimacy of the political process through which projects were selected, rather than the political process resulting 
in better projects being chosen. These effects are large, statistically significant, and seem to occur no matter how the questions were phrased. Villagers also indicate that they are substantially more likely to contribute voluntary labor or materials to KDP projects in villages where plebiscites were held. The striking results on citizen satisfaction and legitimacy results confirm the view of some democratic theorists that broad participation in the political process can be a legitimizing force, even if the ultimate decisions taken do not change (Lind and Tyler 1988; Fishkin 1991; Benhabib 1996; Ackerman and Fishkin 2004).

The remainder of the paper is organized as follows. Section 2 provides basic information on the KDP program and outlines the experimental design. Section 3 presents the results, showing the impact of the plebiscites on the selected project type (roads, irrigation, education programs, etc), project location, various measures of satisfaction and predicted utilization, knowledge about the program, and public and private discussion of development issues. Section 4 concludes.

\section{Setting, Experimental Design, and Data}

\subsection{The KDP Program}

The Kecamatan (Subdistrict) Development Project, or KDP, is a national Indonesian government program, funded through a loan from the World Bank. KDP began in 1998, and currently finances projects in approximately 15,000 villages throughout Indonesia each year.

In KDP, participating subdistricts, which typically contain between 10 and 20 villages, receive an annual block grant for three consecutive years. Every year, each village in the subdistrict makes two proposals for small-scale infrastructure activities. The village as a whole proposes one of the projects (which I refer to as the 'general project'); women's groups in the village propose the second (which I refer to as the 'women's project'). Once the village proposals have been made, an inter-village forum, consisting of six representatives from each 
village, ranks all of the proposals according to a number of criteria, such as the number of beneficiaries and the project's cost, and projects are funded according to the rank list until all funds have been exhausted; typically, about $50-75 \%$ of villages have at least one project funded each year. ${ }^{1}$

This study focuses on the process by which the village selects its two proposals. The baseline process in KDP works as follows. All Indonesian villages are comprised of between 2 and 7 dusun, or hamlets. For a period of several months, a village facilitator organizes small meetings at the hamlet level; for large hamlets multiple meetings might be held in different neighborhoods within each hamlet. These meetings aim to create a list of ideas for what projects the village should propose. These ideas are then divided into two groups - those that originated from women's only meetings and those suggested by mixed meetings or men's meetings. The village facilitator presents the women's list to a women-only village meeting and the men's and joint ideas to a village meeting open to both genders. While these meetings are open to the public, those that attend represent a highly selected sample, just as in Mansbridge’s (1983) study of Vermont town meetings. In particular, government officials, neighborhood heads, and those selected to represent village groups compose the majority of attendees. A typical meeting would have between 9-15 people representing the various hamlets, as well as various formal and informal village leaders, with on average about 48 people attending in total out of an average village population of 2,200. The groups discuss the proposals, with substantial help from an external facilitator (as in Humphreys, Masters and Sandbu 2006), deciding ultimately on a single proposal from each meeting.

\footnotetext{
${ }^{1}$ At the inter-village forum, the general project proposals and the women's project proposals are officially treated equally.
} 


\subsection{Experimental Design}

The results reported here come from field work conducted between September 2005 and

January 2006. The key intervention studied here is a change in the decision making mechanism: instead of following the meeting-based process described above, some villages were randomly allocated to choose their projects via a direct election-based plebiscite. The idea behind the plebiscite was that it would move the political process from a potentially elite-dominated meeting to a more participatory process that might be less subject to elite capture.

The method for selecting the list of projects to be chosen (i.e., the agenda setting procedure) was the same in both cases - the list of projects to be decided on at the meeting or the list of projects on the ballot was determined from the results of hamlet level meetings, where each hamlet was allowed to nominate one general project and one women’s project. $^{2}$

The plebiscite was conducted as follows. Two paper ballots were prepared - one for the general project and one for the women's project. The ballots had a picture of each project along with a description of the project. Village officials distributed voting cards to all adults in the village who had been eligible to vote in national parliamentary elections held approximately six months previously. The voting cards also indicated the date of the election and the voting place. Voting places were set up in each hamlet (dusun) in the village. ${ }^{3}$ When arriving at the voting place to vote, men received one ballot (for the general project) and women received two ballots (one for the general project, one for the women’s project). The selected project (for both the

\footnotetext{
${ }^{2}$ Note that in East Java and Southeast Sulawesi, the set of projects to be decided amongst - i.e., the agenda - was already fixed at the time the randomization was announced. In North Sumatra, however, the agenda was selected after the randomization was announced, so it is potentially endogenous with respect to the randomization. Appendix A notes that the results are consistent among the two subsamples, suggesting that the results are not substantially affected by the potentially endogenous agenda setting in the North Sumatra villages.

${ }^{3}$ If two hamlets were less than 15 minutes walk from one another, we combined them into one voting precinct with a single voting station. In our sample, six hamlets - located in four villages - used voting stations in a nearby hamlet. To ensure that this is not biasing results, I run two robustness checks. First I limit the sample to villages where all hamlets had ballot boxes, and then I restricted it to hamlets where ballot boxes were located. Results (not shown) remain virtually unchanged.
} 
general and women's project) was the proposal that received a plurality of the votes in the respective vote. Turnout at these elections averaged 807 people, or over $60 \%$ of all eligible voters in the village. ${ }^{4}$ This means that roughly 20 times as many villagers participated in the plebiscites as attended the village meetings in non-election villages. Participation in the plebiscite was approximately balanced between men and women.

The experiment was conducted in two phases. First, Phase I was conducted in 10 villages in East Java Province and 18 villages in North Sumatra Province. Based on qualitative reports from Phase I areas, the experimental protocol was changed slightly, and then run again in Phase II in an additional 18 villages in Southeast Sulawesi Province. The key intervention studied here - the plebiscite treatment - was run identically in both phases of the study; the modifications between the two phases concern how the control group, the meeting-based decision processes, was run. Details of these modifications, and robustness checks to ensure that they are not driving the results, can be found in Appendix A.

The randomization design is shown in Table $1 .{ }^{5}$ In Phase I of the project, 25\% of villages were allocated to the plebiscite treatment, whereas in Phase II of the project, $45 \%$ of villages were allocated to the plebiscite treatment. Given these different probabilities, in all specifications I include phase fixed effects, to capture the fact that the treatment probability differed by phase.

A natural question is the degree to which the randomization resulted in a balanced set of villages in the two treatment conditions. To investigate this, I estimate the following Probit specification:

\footnotetext{
${ }^{4}$ As I do not have data on the number eligible voters, I estimate the number of turnout by taking the total village population and multiplying by 0.667 , which is the average ratio of adult population to total population in similar areas of Indonesia (author's calculations).

${ }^{5}$ In Southeast Sulawesi, the treatment assigned to three villages was changed after the randomization was determined. To maintain the exogeneity of the random assignment, in all analysis in this paper I use the results of the original randomization, rather than the final treatment status, in conducting the analysis. The analysis should therefore be interpreted as intent-to-treat effects (Angrist, Imbens and Rubin 1996); treatment-on-treated effects would be slightly larger than the results reported here.
} 


$$
\operatorname{Pr}\left(\text { ELECTION }_{v}\right)=\Phi\left(\alpha_{\text {phase }}+X_{v}^{\prime} \beta\right)
$$

where $v$ is a village and phase refers to whether the villages was in Phase I or Phase II of the project. The results are shown in Table 2. The vector $X$ includes village population, the average village agricultural wage, percent of village roads that are asphalt, hamlets per village, total churches and mosques per village, distance to the subdistrict capital, and the age and educational attainment of the village head. A test for joint significance gives a p-value of 0.28 , indicating that the assignment of treatments was, in fact, orthogonal to observable village characteristics.

\subsection{Data}

The analysis here uses three data sources. First, a panel household survey was conducted, in which five households were randomly sampled in each village. This household survey was conducted in two waves, one at the inception of the study and one after the project selection process was concluded. ${ }^{6}$ The household survey contains information on a standard set of household characteristics, such as assets (used to predict expenditure). Respondents ranked potential projects in order from most to least preferred. The same respondents were resurveyed in the second wave, in which they also responded to a number of questions about their perceptions of and satisfaction with the KDP project in their village.

Second, a survey was conducted in which we asked the village head, and the head of every hamlet, a number of background questions about the condition of the village. The survey also elicited their preferences about types of projects, which I refer to in the analysis as 'elite'

\footnotetext{
${ }^{6}$ Due to time pressures at the beginning of the project, the first wave of the household survey was contemporaneous to the announcement of the randomization in East Java and Southeast Sulawesi. I therefore focus on results using the second wave of the household survey.
} 
preferences. ${ }^{7}$ Third, detailed data (type and location) was collected about the list of projects on the agenda, and about the projects actually selected.

\section{Results}

This section discusses the main findings. Section 3.1 presents results on the impact of the plebiscites on the types and location of projects selected. Section 3.2 shows the effect of the plebiscites on subjective measures of satisfaction with the project. Section 3.3 discusses the impact of the plebiscites on informal discussions about the project and on citizen knowledge about the outcomes of the political process.

\subsection{Impacts on project selection}

\subsubsection{Project types}

Projects have two main attributes: project type - i.e., is the project a road, bridge, irrigation system, etc. - and project location, i.e., in which areas of the village the project is located.

To begin, Table 3 presents summary statistics about types of projects. The first two columns show the breakdown of project types that were actually selected by the program, for both the general proposal (column 1) and the women's proposal (column 2). The general project is much more likely to be a road or bridge (64\% for general project compared to $35 \%$ for women's project), whereas the women's project is much more likely to be a drinking water supply system ( $27 \%$ vs. $8 \%)$.

The remaining columns of Table 3 show respondents' most preferred project type, broken down by various demographic characteristics, according to the responses from the first wave of the household survey. Columns (3) and (4) break down preferences by gender. Note that the

\footnotetext{
${ }^{7}$ The time pattern of these surveys was identical to that of the first round of the household survey - i.e., before randomization was announced in North Sumatra, and contemporaneous with randomization in East Java and Southeast Sulawesi.
} 
differential preferences by gender match almost exactly the differences in the actual project selections - men are more likely to prefer roads or bridges (64\% for men vs. $38 \%$ for women), and women are more likely to prefer drinking water projects than men (23\% to $3 \%)$. This provides suggestive evidence that, in equilibrium, the project selected by the women's process reflects the opinions of women in the village, whereas the general project reflects the preferences of men in the village. ${ }^{8}$

The next four columns, which split households by per-capita expenditure quartile (where quartiles are constructed separately for each province), show that richer households are also more likely to prefer roads, whereas poorer ones tend to prefer irrigation projects, which may reflect the fact that the poor are more likely to be in agriculture than involved in trading or services. Finally, the final two columns show that landowners prefer irrigation projects more often than landless individuals.

The first question about the impact of the plebiscites is their impact on the types of projects selected. Figure 1 shows, for both the general project and the women’s project, the composition of selected projects broken down by whether the village was a plebiscite village or a meeting village. As is evident from Figure 1, there were no changes whatsoever in the types of projects selected as the 'general project' across the two different treatment conditions. For the 'women's project,' some differences emerge - the projects chosen by plebiscite were slightly more likely to be roads and bridges (i.e., moving away from women's stated preferences as shown in Table 3) and water/sanitation systems (i.e., towards women's stated preferences as shown in Table 3), and substantially less likely to be irrigation projects.

\footnotetext{
${ }^{8}$ Note that this does not necessarily imply that women's preferences would not be represented without the special project reserved for women, as it is possible that the separate reservation for women turns the general project into the 'men's project,' a phrase we heard frequently in qualitative work in project villages. However, the experimental evidence from India suggests that reservations for women can cause projects selected to more closely resemble women's preferences, at least in the setting studied there (Chattopadhyay and Duflo 2004).
} 
To estimate the statistical significance of the changes shown in Figure 1, I estimate a conditional logit model via maximum likelihood (following McFadden 1974). Adapting the standard conditional logit notation, denote by $P_{v}$ the number of project types (i.e., road, irrigation, etc.) in village $v$ and $T_{v}$ the total number of types selected in that village (which will almost always be equal to 1 ). Denote $d_{v p}$ to be a dummy variable equal to 1 or 0 , and denote by $S_{v}$ the set of all possible vectors $\mathbf{d}_{v}=\left\{d_{v 1}, \ldots, d_{v P_{v}}\right\}$ such that $\sum_{p=1}^{P_{v}} d_{v p}=T_{v}$. I then estimate the following model:

$$
\begin{aligned}
\operatorname{Pr}\left(\text { CHOSEN }_{v} \mid\right. & \left.\sum_{p=1}^{P_{v}} \operatorname{CHOSEN}_{v p}=T_{v}\right)= \\
& \frac{\exp \left[\sum_{p=1}^{P_{v}} \operatorname{CHOSEN}_{v p}\left(\alpha_{p \times p h a s e}+\beta_{j} \text { ELECTION }_{v} \times \gamma_{p}\right)\right]}{\sum_{\mathbf{d}_{v} \in S_{v}} \exp \left[\sum_{p=1}^{P_{v}} d_{v p}\left(\alpha_{p \times p h a s e}+\beta_{j} \text { ELECTION }_{v} \times \gamma_{p}\right)\right]}
\end{aligned}
$$

where $C H O S E N_{v p}$ is a dummy variable equal to 1 if project type $p$ was chosen in village $v$ and 0 if not, and $\mathbf{C H O S E N _ { v }}$ indicates the vector of projects chosen in village v. ELECTION equals 1 if the village chose its project proposal via plebiscite and 0 otherwise. I group the 8 project types into four major categories - roads/bridges, irrigation, water/sanitation, and other - to preserve statistical power. The omitted category in the regression is 'other,' which consists of educational and health projects. Robust standard errors are adjusted for clustering at the village level. The key coefficients of interest are the interactions of the project types $\times$ election (i.e., the $\beta_{j}$ 's), which indicates the differential likelihood a particular type of project is chosen in plebiscitebased villages relative to meeting-based villages.

The results from estimating equation (2) are presented in Table 4. The first 3 columns show the results when all options are considered; the last 3 columns restrict the sample to the 
subset of types that were actually available as agenda items in that village. (The second specification has more power, but I present both given that it is theoretically possible that there was the potential for endogeneity in available project types in North Sumatra villages, given the timing of the experiment.) The coefficients are interpretable as log odds ratios. The results confirm the picture shown in the Figure 1. For the general project, the point estimates are generally small, and highly statistically insignificant - a joint F-test has a p-value of 0.79 or 0.87 , depending on the specification. For the women's project, the point estimates indicate substantial increases in the probability of choosing either roads / bridges and water / sanitation projects, though given the small sample sizes these shifts are not statistically significant (p-values from a joint F-test of 0.55 and 0.18 , depending on specification).

While the overall preferences for different types of projects reported in Table 3 give some indication of which project types were preferred by which types of people, I can estimate more directly whether the project resulted in chosen projects that were more or less preferred by different subsets of villagers. Recall that in the first household survey, respondents were asked to rank each of the eight potential project types from most preferred (1) to least preferred (8). I can therefore estimate the following conditional fixed-effects logit regression:

$$
\begin{aligned}
& \operatorname{Pr}\left(\text { CHOSEN }_{v h} \mid \sum_{p=1}^{P_{v}} \text { CHOSEN }_{v h p}=T_{v}\right)=
\end{aligned}
$$

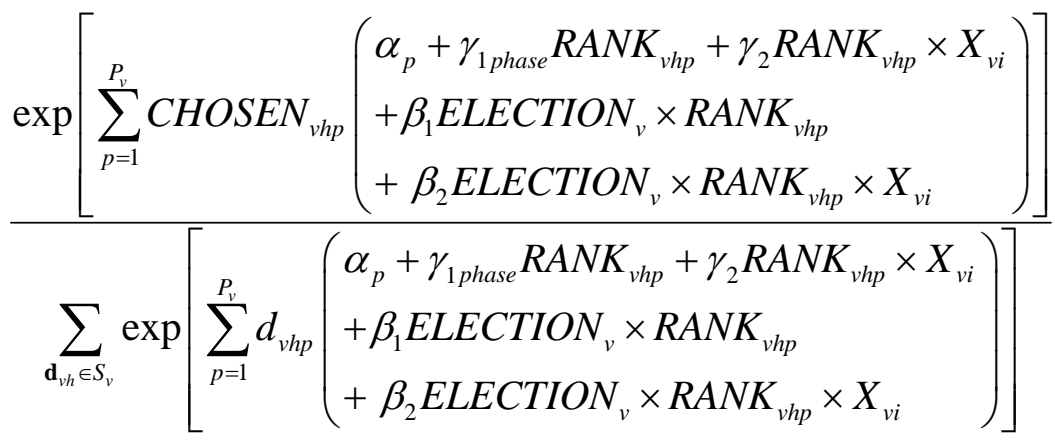


where $v$ is a village, $p$ is a project type, and $h$ is the respondent. Note that the coefficient $\gamma_{1}$ is allowed to vary by project phase, to take into account the fact that the probability of ELECTION differed between phase 1 and phase 2 villages. CHOSEN $N_{\text {vhp }}$ equals 1 if the project type $p$ was chosen by respondent $h$ 's village $v$ and 0 if it was not. $R A N K_{v h p}$ is respondent $h$ 's rank of project $p$ in village $v$, where the top-project is ranked 1 , the second project is ranked 2, etc. Robust standard errors are clustered by village, to take into account the fact that there are multiple respondents in each village.

The key coefficients of interest are the interactions of ELECTION and RANK (i.e., $\beta_{1}$ ), and the triple interactions of ELECTION, RANK, and individual characteristics $X$ (i.e., $\beta_{2}$ ). A negative coefficient on the triple interaction indicates that the plebiscite made projects preferred by individuals with the respective characteristic $X$ more likely to be chosen.

The results are shown in Table 5. The first column shows the overall impact of plebiscites on the probability that low-ranked (i.e., preferred) project types are likely to be chosen; the second column focuses on whether projects preferred by elites are more likely to be chosen when elections are utilized, and the third column investigates a host of individual characteristics. ${ }^{9}$ For the general project, I find no effects, which is not surprising given the results above that show that there was almost no impact of the plebiscite on the types of projects chosen as the general project. For the women's project, the negative coefficient on ELITE $\times$ RANK $\times$ ELECTION in column (8) indicates that the plebiscites make the project chosen by the women’s process look more like the preferences of the village elite and less like the preferences of ordinary villagers, although the coefficient is of only borderline statistical significance $(p=0.096)$. Similarly, the

\footnotetext{
${ }^{9}$ Columns (2) and (3) are estimated separately, since the detailed $X$ characteristics shown in column (3) are not available for the elite sample.
} 
negative coefficient on the triple interaction of log HH per-capita expenditure, RANK, and ELECTION indicates that the relatively affluent are more likely to have their highly ranked projects selected as the women's proposal when plebiscites are utilized than when meetings are used. These results are likely driven by the fact that roads are more likely to be chosen as the women's project in the plebiscite treatment, and roads are preferred by the elites, by men, and by the wealthy.

\subsubsection{Project Location}

In practice, qualitative evidence suggests that the key political question to be determined in the KDP process is not the type of project, but rather where the project should be located. Each area of the village may have their own preferred project type, but virtually everyone in the village I interviewed reported that they would strongly prefer a suboptimal project type in their own hamlet to their most preferred project type located somewhere else in the village where they would not be able to use it.

Under the assumption that everyone's most preferred project is a project in their own hamlet, moving from a meeting-based system to a plebiscite-based system has several clear predictions. First, the representative meeting process allocates equal numbers of votes in the meeting to each hamlet, whereas in the plebiscite, the number of votes likely depends on population (assuming a uniform participation rate in elections). This suggests that one would expect the plebiscite to favor hamlets with large populations relative to the meeting treatment (Ansolabehere, Gerber and Snyder 2003).

Second, the meeting is typically held in the village town hall. Although votes are allocated in meetings equally to each hamlet, the meeting's location in the village town hall means that the number of attendees at the meeting is typically skewed in favor of hamlets located 
close to the village town hall. To the extent that these people can influence the meeting even though they cannot vote (for example, by dominating the conversation), one would expect that the plebiscites would favor more outlying hamlets, given that polling stations were located in each hamlet.

The predictions on whether the plebiscite should locate projects in poorer areas are less clear. To the extent that the number of attendees at meetings determines who attends meetings, one might expect the poor to be less likely to attend meetings. Since the cost of voting in an election is much lower than the cost of attending a meeting (10 minutes vs. 3 hours), it is plausible that the poor might be relatively more likely to vote than to attend meetings, in which case the plebiscite treatment would increase the power of the poor. ${ }^{10}$ More generally, meetings may be more easily captured by elites than elections, since elite individuals may be more vocal at meetings than poorer villagers (Olken 2007).

To examine these questions, I first plot the probability distribution of the selected project according to various village characteristics. As can be seen in Figure 2, plebiscites did not change the probability that the general project would be located in a poor relative to a wealthy hamlet, but they did increase the likelihood that selected women's projects would be constructed in relatively impoverished hamlets. (Hamlets were ranked in terms of their poverty by the village head before the project began.) Thus, while plebiscites may have led selected project types for the women's proposal to move closer to the preferences of the elite, they simultaneously increased the likelihood that selected projects would be located in poorer areas of the village.

\footnotetext{
${ }^{10}$ Technically this relationship is ambiguous, since the poor have lower incomes (and thus a higher utility of money, and more of a need to work) but also lower wages (and therefore a lower opportunity cost of time), and it is not clear theoretically which effect dominates. Jayachandran (2006) finds evidence that income effects are particularly important in the context of poor, rural villagers in developing countries.
} 
Plebiscites affect locations of projects in other ways as well. Figure 3 shows that, contrary to the predictions outlined above, plebiscites also resulted in projects being more likely to be located in less populous hamlets, rather than more populous hamlets. This is particularly true for the general project. This goes directly against the hypothesis that the plebiscite should help more populous areas. One possibility, suggested by the experience of several villages in fieldwork, was that in a situation where there are more than two hamlets, no hamlet has an outright majority. Large hamlets may be tempted to go it alone, hoping to win with a plurality, whereas small hamlets may better foresee the need to form coalitions in order to win.

Finally, as shown in Figure 4, plebiscites decreased the probability that projects selected by both the general and women's proposals would be constructed in isolated hamlets - i.e., those hamlets that are located furthest from the center of the village (I group hamlets into quartiles according to their distance from the center of the village). This is also surprising, given that outlying hamlets tend to have fewer supporters at village meetings, but should have had an easier time voting in the election, since the election was held in each hamlet.

To investigate the impact on project location more systematically (and, in particular, to control for these various factors simultaneously), I estimate conditional logit specifications of the form:

$$
\begin{aligned}
\operatorname{Pr}\left(\text { CHOSEN }_{v} \mid\right. & \left.\sum_{d=1}^{D_{v}} \operatorname{CHOSEN}_{v d}=T_{v}\right)= \\
& \frac{\exp \left[\sum_{d=1}^{D_{v}} \operatorname{CHOSEN}_{v d}\left(\gamma_{\text {phase }} X_{v d}+\beta \text { ELECTION }_{v} \times X_{v d}\right)\right]}{\sum_{d_{v d} \in S_{v}} \exp \left[\sum_{d=1}^{D_{v}} d_{v d}\left(\gamma_{\text {phase }} X_{v d}+\beta \text { LECTION }_{v} \times X_{v d}\right)\right]}
\end{aligned}
$$

where $v$ is a village and $d$ is a hamlet (dusun). Once again the coefficients $\gamma$ are allowed to vary by project phase. $C H O S E N_{v d}$ equals 1 if the hamlet was chosen for project construction and 0 if 
not. $X$ indicates a group of hamlet characteristics. The coefficients of interest are $\beta$, which represent the differential likelihood of a hamlet of type $X$ receiving the project in election areas vs. non-election areas. Robust standard errors are clustered by village.

The results are presented in Table 6. These results confirm the qualitative patterns shown in the Figures. For the women's project, the results indicate that the plebiscites resulted in projects that were more likely to be located in poorer hamlets. Particularly for the general project, the plebiscite also resulted in projects that were located in less populous, but more centrally located, hamlets. ${ }^{11}$

\subsubsection{Interpretation of results}

Overall, the data suggests that the main effect of plebiscites was limited to the women's project. For the women's project, the plebiscites resulted in projects located in poorer hamlets, but also in projects that looked closer to preferences of the village elites. One way of reconciling these two results is to recall that, in the experimental design, the plebiscite process did not affect the agenda setting within these hamlets. It is possible that in poorer hamlets, poor women were less involved in the agenda setting stage, so the women's projects proposed in these hamlets were more elite dominated. When time came to vote, however, the newly enfranchised poorer women may have preferred to vote for sub-optimal project type located in their area than in an optimal project type located too far away to be useful. This suggests that while the plebiscite process is successful to some degree at enfranchising poorer women in the final decision making process, fully enfranchising poorer women would require increasing their participation at the agenda-setting stage as well.

\footnotetext{
${ }^{11}$ As an aside, the overall coefficient (as opposed to the interaction) on hamlet poverty shows that, at least based on the village head's ranking of which hamlets are richest and which are poorest, poorer hamlets are more likely to subsequently receive the general project, both with and without the direct elections. This pattern can also be seen in Figure 3.
} 
An interesting question is why the change in political process affected the selection of projects much more in the women's project than in the general project. Qualitative evidence from the study villages suggests one potential explanation for these differential results. In particular, men - who often dominate the discussion surrounding the general project - may be able to strike deals amongst themselves in which those who lose out from the political process in one year receive benefits in a future year. If so, the change in political power induced by the plebiscite treatment may have changed the allocation of these future promises, even if the project chosen this year remained unchanged - i.e., this may be an empirical example of what has been termed a Political Coase Theorem (Acemoglu 2003). ${ }^{12}$ The elite men in the village are able to make these types of dynamic commitments to one another because they are frequently involved in village decision making, so promises can be sustained by their repeated future interactions. For women, whose political power in the KDP process studied here is very much the exception to village politics rather than the norm, the political process investigated here may have been more of a one-shot game, making it difficult to offset the change in political power induced by the plebiscite with promises of future transfers.

\subsection{Project Satisfaction and Support}

The previous analysis has shown that plebiscites had relatively little impact on the types of projects chosen for the general project and served to move the selected women’s projects towards the types of projects chosen by village elite. One might expect, given these results, that the plebiscite process would not have been particularly popular in the villages.

\footnotetext{
${ }^{12}$ For example, in one village visited by the author, the village head explained that, prior to knowing about the experiment, he had been planning on using his influence at the meeting to channel project resources towards a section of his village known as Hamlet Five, which had not yet received a development project during his tenure as village head and whose support he needed in the upcoming village head election. In response to the election treatment, the village head convinced the citizens of the section of the village known as Hamlet Four to vote for Hamlet Five's project in the general project election by promising them that, in the future, he would lobby the district government to bring an additional road project to Hamlet Four.
} 
However, the opposite is true. Table 7 shows the impact on responses, from the second round of the household survey, of people's perceptions about the KDP decision-making process in their village. Each cell in Table 7 is the coefficient $\beta$ from the following ordered probit specification:

$$
\begin{aligned}
\operatorname{Pr}\left(\text { OUTCOME }_{v h j}\right) & =\Phi\left(\alpha_{\text {phase }}+\delta_{j+1}+\beta \text { ELECTION }_{v}+X_{v_{v} \gamma}^{\prime} \gamma\right)- \\
& \Phi\left(\alpha_{\text {phase }}+\delta_{j}+\beta \text { EECTION }_{v}+X_{{ }_{v} h}^{\prime} \gamma\right)
\end{aligned}
$$

For all outcomes, more 'positive' answers have been consistently coded as having higher ordered response values. All shown variables have 4 possible response categories except for "will you use the project,” which is binary. I cluster standard errors by village to take into account that there are multiple respondents $h$ in each village $v$. The vector $X$ represents a set of respondent control variables (gender, age, log per-capita expenditure, number of household members, and occupation dummies). Table 7 presents both pooled results and results separated out by the type of project (general and women's) and gender of respondent.

As can be seen in Table 7, the plebiscite process resulted in greater villager satisfaction across a wide variety of measures. In the elections villages, villagers were more likely to report that the project was chosen in accordance with their wishes, was more likely to benefit them personally, and that they were more likely to use the project. They are also more likely to respond that the project was fair, that the project was chosen in accordance with the 'people's aspirations' (aspirasi masyarakat - a broad measure of legitimacy), and that they were satisfied with the KDP project overall.

The magnitude of these changes in satisfaction is substantial. To interpret the magnitudes, note that overall, the plebiscites resulted in an increase in 21 percentage points of people who said that the project chosen was in either very much or somewhat in accordance with their 
wishes, an increase of 18 percentage points of people who said they would benefit either very much or somewhat from the project, an increase of 8 percentage points of people who said they would use the project personally, and increase overall satisfaction with the KDP program by 13 percentage points.

Several points are worth making about these results. First, note that for the general project, reported satisfaction increased for both male and female respondents across a wide variety of the measures. By contrast, for the women's project, the increases in satisfaction came only on the part of female respondents, who were the only ones to participate in the decision making process for the women's project. Thus the increases in satisfaction precisely mirror the increases in participation - for both men and women for the general project, and for women only for the women's project - which suggests that participation itself may be responsible for the increases in satisfaction. Second, there were marked increases in satisfaction with the general project, despite the fact that - as shown above - the actual project chosen as the general project barely changed as a result of the plebiscite treatment. Specifically, the results in Table 5 show that the plebiscite did not change the probability that types of projects that were ranked higher by respondents were chosen, and the results in Table 6 showed that for the general project, the treatments resulted in projects in centrally located, but less populous hamlets - not necessarily changes that one would have thought ex-ante would have led to dramatically larger improvements in satisfaction. This also suggests that it is participation itself that may matter for satisfaction, since the outcomes of the project barely changed. Together, these results suggest that changes in the political process can affect satisfaction or legitimacy, even if those changes do not necessarily affect the outcome of the process (e.g., Lind and Tyler 1988; Fishkin 1995). 
An interesting question is whether this increased stated support would translate into increased material support for the project. Although the study did not cover the actual construction phase, the second round of the household survey asked respondents about their plans for making voluntary contributions to the project. ${ }^{13}$ Again estimating equation (5), Table 8 shows that plebiscites substantially increased villagers' intentions to contribute to KDP project construction, particularly for the general project. Specifically, plebiscites raised the probability that individuals stated that they would contribute something (i.e. labor, money, food) to project construction by 18 percentage points. The majority of this is driven by planned labor contributions, which increase by 16 percentage points. ${ }^{14}$ Perhaps surprisingly, the plebiscite slightly decreased the probability that respondents would contribute money ( $7 \%$ of respondents planned to contribute money when meetings were used, versus only $5 \%$ when plebiscites were used.) Nevertheless, to the extent these stated intentions were subsequently manifested in actual contributions, they would represent a substantial impact of the plebiscites on the general project.

\subsection{Knowledge and Discussions}

In political science, several theorists have argued that active discussions of issues among citizens are important both to increase legitimacy and to help citizens discover the socially optimal outcome (Fishkin 1991; Ackerman and Fishkin 2004). These types of discussions can take place in public forums, but can also take place in a variety of private settings or informal discussions outside the formal political process (Benhabib 1996). One might expect, in a plebiscite that involved an order of magnitude more people, that than ordinary citizen’s discussions of the project would increase in preparation for the plebiscite.

\footnotetext{
${ }^{13}$ Note that given the design of KDP, this question could not have been answered using actual contribution data even if the study had included the construction phase, since which proposals were actually funded by the intervillage council, and thus for which projects we would observe actual contributions, is endogenous.

${ }^{14}$ Note that $70 \%$ of those surveyed planned to contribute labor when meetings were utilized, whereas $84 \%$ did when elections were utilized. This 14 percentage point increase is slightly different from the 16 percentage point estimate in the Table because the estimate in the Table includes phase fixed effects.
} 
To investigate the degree to which the change in political process affected these discussions, I use data from the second-round household survey in which households were asked about the degree to which they had discussed village development issues in the period before the survey. Table 9 reveals that plebiscites do not impact private and public dialogue about development issues, at least not in the short timeframe within which this study was conducted. Specifically, I detect no statistically significant difference in the probability that a respondent discussed 'development issues in the village' in the last three months with anyone, with household members, or with members of the village government. One possibility, however, is that the increase in dialogue is on the intensive margin, rather than the extensive margin, in which case it would not be detected by these questions. This is certainly possible given that the baseline levels of these discussions were quite high to begin with. Nevertheless, it is remarkable that the dramatic increases in participation associated with the plebiscites treatment did not result in detectable additional discussions among citizens.

A second important measure of civic engagement is the degree to which individuals are knowledgeable about the outcome of the political process. To investigate this, Wave 2 of the household survey also asked respondents to name the type and location of selected KDP proposals in their villages. Table 9 shows, again by estimating equation (5), that plebiscites substantially increase knowledge about the projects. When plebiscites are utilized, respondents are 22 percentage points more likely to correctly identify the type and location of the selected general proposal and 29 percentage points more likely to do so for the women's proposal. Female respondents are 37 percentage points more likely to be able to correctly identify the women's proposal in the plebiscite treatment. Thus, although there was little detectable increase 
in whether citizens had any discussions about village development, villagers were certainly much more aware of the outcomes of the political process in the plebiscite treatment.

\section{Conclusion}

This project investigated two alternate mechanisms through which villagers could choose how to spend money for infrastructure projects in their village: a representative meeting and a plebiscite. Each village selected two projects, a general project, chosen by all villagers, and a women's project, chosen exclusively by the women in the village. These experimental interventions affected only the final choice of which would be selected - the process of setting the agenda, in which each hamlet in the village nominated one general project and one women's project through a series of hamlet-level meetings, was unchanged across the experimental treatments.

The experiment found very different results for the two projects considered. For the general project, the plebiscite process resulted in substantially higher villager satisfaction with the political process, even though it had very limited impacts on the actual projects selected. For the women's project, not only did women's satisfaction increase, but the plebiscite process resulted in women's projects that were more likely to be located in poorer hamlets of the village.

One potential explanation for the difference between the general project and the women's project is that, for the general project, promises of future transfers may have been used to undo the change in political power from the plebiscite. These deals may have occurred in the general project, but not in the women's project, because male elites from different hamlets are involved in village decision making every year, so their repeated interactions allow them to enforce agreements over time. By contrast, the KDP project was unusual in the role reserved for women, so women were in effect playing a one-shot game in which they could not credibly commit to 
future transfers. The ability of elites to enforce these types of inter-temporal commitments through their repeated interactions suggests a potentially beneficial role that elites may play in local politics, and is consistent with the theoretical requirements for a Political Coase Theorem to hold.

An important caveat is that this study was conducted in only 48 villages. Therefore, while the results that show large, statistically significant impacts on satisfaction and legitimacy are clearly valid, some caution must be used in interpreting the relative lack of an impact on project type and project location for the general project, as there might have been small effects that would only have been detectable in a larger study. Nevertheless, if such effects existed, they were of much smaller order of magnitude than the effects of the plebiscite on citizen perceptions of fairness, legitimacy, and satisfaction with the project, which are large enough to be detected even in this relatively small sample size.

Although the experiment was conducted at the village level, the results speak to the broader debate about participatory vs. deliberative approaches to democracy more generally. In particular, the dramatically higher levels of citizen satisfaction with the plebiscite treatment, in which citizens could vote directly on which proposal they wish to have, may help explain the growth of citizen referenda and initiative petition systems, despite the many issues associated with such systems (Matsusaka 2005a; Matsusaka 2005b). The striking results on citizen satisfaction and legitimacy results confirm the view that broad participation in the political process can be a legitimizing force, even if the ultimate decisions taken do not change. 


\section{References}

Acemoglu, Daron (2003). "Why not a political Coase theorem? Social conflict, commitment, and politics." Journal of Comparative Economics 31(4): 620-652.

Ackerman, Bruce A. and James S. Fishkin (2004). Deliberation Day. New Haven, Yale University Press.

Angrist, Joshua D., Guido W. Imbens and Donald B. Rubin (1996). "Identification of Causal Effects Using Instrumental Variables." Journal of the American Statistical Association 91(434).

Ansolabehere, Stephen, Alan Gerber and James Snyder (2003). "Equal Votes, Equal Money: Court-Ordered Redistricting and Public Expenditures in the American States." American Political Science Review 96(04): 767-777.

Bardhan, Pranab (2002). "Decentralization of Governance and Development." Journal of Economic Perspectives 16(4): 185-205.

Bardhan, Pranab and Dilip Mookherjee (2006). "Decentralization and Accountability in Infrastructure Delivery in Developing Countries." Economic Journal 116: 101-127.

Benhabib, Seyla (1996). Toward a Deliberative Model of Democratic Legitimacy. Democracy and Difference: Contesting the Boundaries of the Political. S. Benhabib. Princeton, NJ, Princeton University Press: 67-94.

Chattopadhyay, Raghabendra and Esther Duflo (2004). "Women as Policy Makers: Evidence from a Randomized Policy Experiment in India." Econometrica 72(5): 1409-1443.

Druckman, James N., Donald P. Green, et al. (2006). "The Growth and Development of Experimental Research in Political Science." American Political Science Review 100(4): 627-635.

Eldersveld, Samuel J. (1956). "Experimental Propaganda Techniques and Voting Behavior." American Political Science Review 50(1): 154-165.

Fishkin, James S. (1991). Democracy and deliberation : new directions for democratic reform. New Haven, Yale University Press.

Fishkin, James S. (1995). The voice of the people : public opinion and democracy. New Haven, Yale University Press.

Gerber, Alan. S. and Donald P. Green (2000). "The Effects of Canvassing, Telephone Calls, and Direct Mail on Voter Turnout: A Field Experiment." American Political Science Review 94(3): 653-663. 
Green, Donald P. and Ian Shapiro (1994). Pathologies of rational choice theory : a critique of applications in political science. New Haven, Yale University Press.

Humphreys, Macartan, William Masters and Martin E. Sandbu (2006). "The Role of Leaders in Democratic Deliberations: Results from a Field Experiment in Sao Tome and Principe." World Politics 58: 583-622.

Jayachandran, Seema (2006). "Selling Labor Low: How Workers Respond to Productivity Shocks in Developing Countries." Journal of Political Economy 114(3): 538-575.

Lind, E. Allan and Tom R. Tyler (1988). The Social Psychology of Procedural Justice. New York, Plenum Press.

Mansbridge, Jane J. (1983). Beyond Adversary Democracy. Chicago, University of Chicago Press.

Matsusaka, John G. (2004). For the Many or the Few: The Initiative, Public Policy, and American Democracy, University Of Chicago Press.

Matsusaka, John G. (2005a). "Direct Democracy Works." Journal of Economic Perspectives 19(2): 185-206.

Matsusaka, John G. (2005b). "The eclipse of legislatures: Direct democracy in the 21st century." Public Choice 124(1): 157-177.

McFadden, Daniel (1974). Conditional logit analysis of qualitative choice behavior. Frontiers in Econometrics. P. Zarembka. New York, Academic Press.

Olken, Benjamin A. (2007). "Monitoring Corruption: Evidence from a Field Experiment in Indonesia." Journal of Political Economy 115(2): 200-249.

Stiglitz, Joseph E. (2002). "Participation and Development: Perspectives from the Comprehensive Development Paradigm." Review of Development Economics 6(2): 163192.

Wantchekon, Leonard (2003). "Clientelism and Voting Behavior: Evidence from a Field Experiment in Benin." World Politics 55(3): 399-422.

World Bank (2004). World Development Report 2004: Making Services Work For Poor People. Washington, DC, World Bank.

\section{Appendix A}

As discussed in the text, in addition to the main plebiscite / meeting-based system discussed at length in the paper, several additional experimental sub-treatments were run in both Phase I and Phase II of the experiment. This Appendix discusses briefly these additional subtreatments and robustness exercises that show that these sub-treatments are not driving the main results discussed in the paper. 
In Phase I of the experiment, there were three sub-versions of the meetings treatment: open meetings, in which all villagers who attended meetings were eligible to vote, representative meetings, in which each hamlet (in North Sumatra) or neighborhood (in East Java) elected a representative to each meeting, and limited representative meetings, in which each hamlet (in North Sumatra) or neighborhood (in East Java) elected a representative and in which the representatives (or immediate family members) were not allowed to have had any previous government experience. The idea of these additional sub-randomizations was to investigate how different attendees at the meetings affected the results of the meetings.

In addition, meetings were randomized into a) using either a single round plurality voting system (as in the plebiscites) or a multiple round voting system where votes would continue until a single project received a majority of votes and $b$ ) using either public or private ballots.

In Phase II of the experiment, different sub-treatments were run in the meeting treatment: a) to investigate commitment issues, the meeting villages were randomized into deciding whether to plan for 1 or 2 year's worth of projects and b) participants held 15-minute discussions in which they were grouped either within-hamlet or across-hamlets.

For the main results of the paper, I group all of these results into the category 'meetings.' However, I have repeated the main results of the paper dropping each of these sub-varieties of meetings one-by-one, and the main qualitative results of the paper (in particular, on location of project and satisfaction with project) are robust to dropping each of these sub-treatments. This ensures that the results reported here really are being driven by the plebiscites treatment, rather than one of the sub-varieties of the meeting experiment. 
Table 1: Experimental Design

\begin{tabular}{lll} 
Province & Plebiscite & Meetings \\
\hline Phase I & 5 & 13 \\
North Sumatra & 3 & 7 \\
East Java & & \\
Phase II & 9 & 11 \\
Southeast Sulawesi & 9 &
\end{tabular}

Notes: Each cell displays the number of villages in each treatment.

\section{Table 2: Randomization Test}

\begin{tabular}{lc}
\hline & $(1)$ \\
\hline Village population (1000 inhabitants) & 0.011 \\
& $(0.048)$ \\
Agricultural wage (1000 rupiah) & -0.013 \\
& $(0.015)$ \\
Percent village roads that are asphalt & -0.117 \\
& $(0.325)$ \\
Number of hamlets per village & $-0.103^{* *}$ \\
& $(0.051)$ \\
Number of churches and mosques & -0.018 \\
per village & $(0.063)$ \\
Distance to subdistrict capital (km) & 0.020 \\
& $(0.021)$ \\
Village head age & 0.015 \\
Village head years of education & $(0.012)$ \\
Phase fixed effects & -0.007 \\
Observations & $(0.039)$ \\
P-value from joint test & YES \\
\end{tabular}

Notes: Robust standard errors are in parentheses. Column (1) presents marginal effects from a Probit regression. The unit of observation is the village, and the dependent variable is a dummy equal to one if the village received the plebiscite treatment. * significant at $10 \%$; ** significant at $5 \%$; *** significant at $1 \%$. 
Table 3: Project types

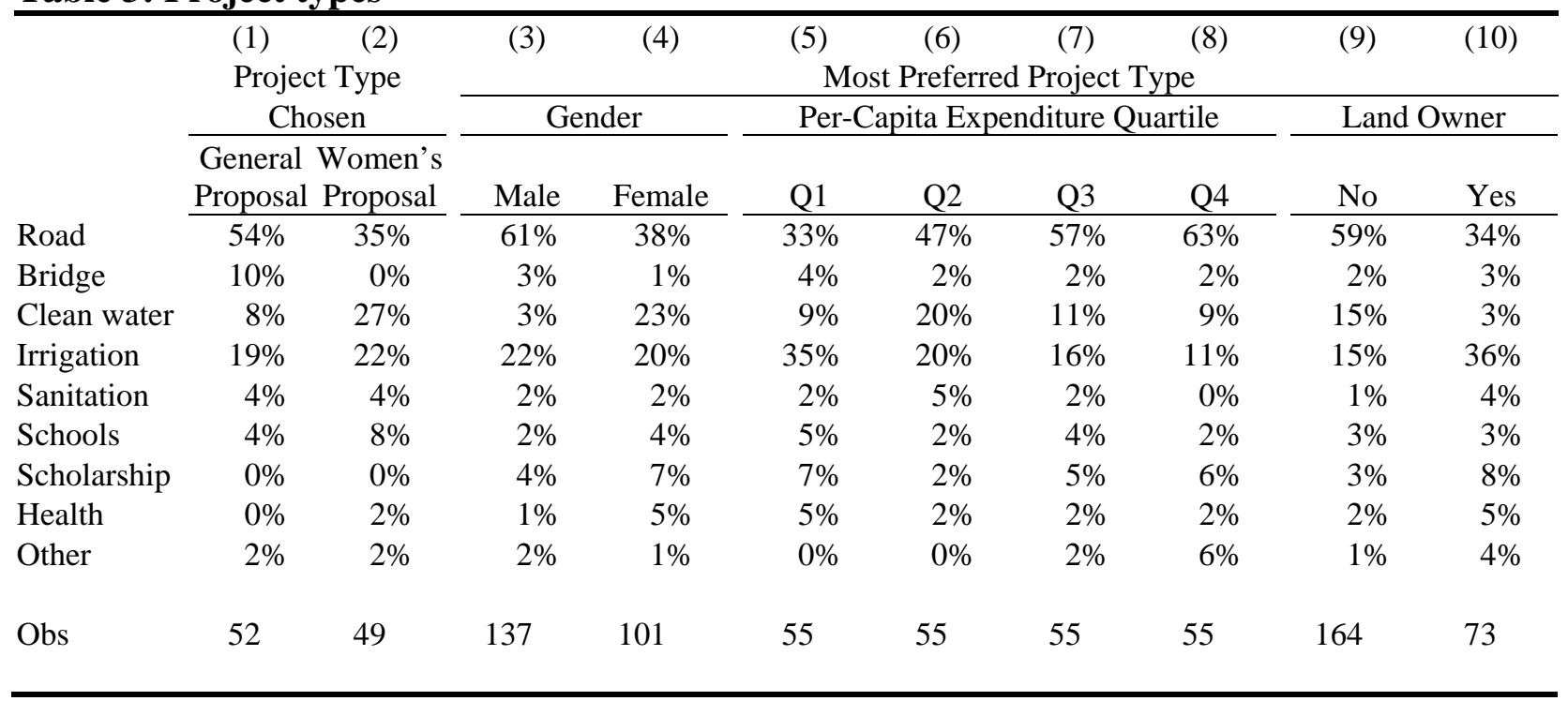

Notes: Data in columns (1) and (2) show the project types chosen by the village, for the general and women's project respectively. Number of observations can be greater than the number of villages because several projects fell into multiple types. Columns (3) through (10) give preferred project of respondents to wave I of household survey type broken down by respondents' gender, estimated per capita household expenditure, and whether or not the respondent owns land. Q1 refers to the poorest income quartile and Q4 to the wealthiest.

Table 4: Impact of Plebiscites on Project Type

\begin{tabular}{|c|c|c|c|c|c|c|}
\hline & (1) & (2) & (3) & (4) & (5) & (6) \\
\hline & \multicolumn{3}{|c|}{ Whole Sample } & \multicolumn{3}{|c|}{ Available Project Types } \\
\hline & $\begin{array}{c}\text { Both } \\
\text { Proposals }\end{array}$ & $\begin{array}{l}\text { General } \\
\text { Proposal }\end{array}$ & $\begin{array}{l}\text { Women's } \\
\text { Proposal }\end{array}$ & $\begin{array}{c}\text { Both } \\
\text { Proposals }\end{array}$ & $\begin{array}{l}\text { General } \\
\text { Proposal }\end{array}$ & $\begin{array}{l}\text { Women's } \\
\text { Proposal }\end{array}$ \\
\hline Road/bridge $\times$ election & $\begin{array}{c}0.601 \\
(0.839)\end{array}$ & $\begin{array}{l}-0.156 \\
(1.112)\end{array}$ & $\begin{array}{c}1.264 \\
(1.141)\end{array}$ & $\begin{array}{c}0.859 \\
(0.835)\end{array}$ & $\begin{array}{l}-0.173 \\
(1.116)\end{array}$ & $\begin{array}{c}1.730 \\
(1.098)\end{array}$ \\
\hline Water/sanitation $\times$ election & $\begin{array}{c}0.353 \\
(0.779)\end{array}$ & $\begin{array}{l}-0.371 \\
(1.327)\end{array}$ & $\begin{array}{c}0.796 \\
(1.345)\end{array}$ & $\begin{array}{c}0.172 \\
(0.759)\end{array}$ & $\begin{array}{l}-0.380 \\
(1.326)\end{array}$ & $\begin{array}{c}0.488 \\
(1.342)\end{array}$ \\
\hline Irrigation $\times$ election & $\begin{array}{c}0.504 \\
(0.978)\end{array}$ & $\begin{array}{c}0.687 \\
(1.195)\end{array}$ & $\begin{array}{c}0.157 \\
(1.291)\end{array}$ & $\begin{array}{c}0.417 \\
(1.124)\end{array}$ & $\begin{array}{c}0.854 \\
(1.466)\end{array}$ & $\begin{array}{l}-0.502 \\
(1.680)\end{array}$ \\
\hline Phase $\times$ project type fixed effects & YES & YES & YES & YES & YES & YES \\
\hline Observations & 384 & 192 & 192 & 306 & 159 & 147 \\
\hline P-value from joint test & 0.85 & 0.79 & 0.55 & 0.46 & 0.87 & 0.18 \\
\hline
\end{tabular}

Notes: Results from conditional fixed-effects logit regression, where each observation is a project type in a village. Robust standard errors in parentheses adjusted for clustering at the village level. The dependent variable is a dummy equal to 1 if the respective project type was chosen by the village. In columns 1 through 3 all four project types are included as alternatives, whereas in columns 4 through 6 only project types available in the respective village are included. Other (education and health projects) is the omitted category. Phase is a dummy variable equal to 1 if the village's treatment was assigned during Phase I of the study (see Table 1). The conditioning variable in columns 1 and 4 is village $\times$ general/women's project and in columns $2,3,5$, and 6 is village.

* significant at $10 \%$; ** significant at $5 \%$; *** significant at $1 \%$. 
Table 5: Impact of plebiscites on project rank

\begin{tabular}{|c|c|c|c|c|c|c|c|c|c|}
\hline & (1) & (2) & (3) & (4) & (5) & (6) & (7) & (8) & (9) \\
\hline & \multicolumn{3}{|c|}{ Whole Sample } & \multicolumn{3}{|c|}{ General Proposal } & \multicolumn{3}{|c|}{ Women's Proposal } \\
\hline \multirow[t]{2}{*}{ Rank $\times$ election } & -0.233 & -0.217 & $8.654^{*}$ & -0.220 & -0.215 & 4.349 & -0.099 & -0.081 & $17.142 * *$ \\
\hline & $(0.218)$ & $(0.207)$ & $(5.213)$ & $(0.235)$ & $(0.235)$ & $(5.813)$ & $(0.215)$ & $(0.214)$ & $(7.832)$ \\
\hline \multirow[t]{2}{*}{ Elite $\times$ rank } & & $-0.079 *$ & & & -0.003 & & & -0.089 & \\
\hline & & $(0.041)$ & & & $(0.050)$ & & & $(0.066)$ & \\
\hline \multirow[t]{2}{*}{ Elite $\times$ rank $\times$ election } & & -0.117 & & & -0.108 & & & $-0.214^{*}$ & \\
\hline & & $(0.108)$ & & & $(0.128)$ & & & $(0.129)$ & \\
\hline \multirow[t]{2}{*}{ Male $\times$ rank } & & & $-0.106^{*}$ & & & -0.036 & & & -0.154 \\
\hline & & & $(0.057)$ & & & $(0.120)$ & & & $(0.124)$ \\
\hline \multirow[t]{2}{*}{ Male $\times$ rank $\times$ election } & & & -0.387 & & & -0.357 & & & -0.613 \\
\hline & & & $(0.276)$ & & & $(0.275)$ & & & $(0.505)$ \\
\hline \multirow[t]{2}{*}{ HH p.c. expend. $\times$ Rank } & & & -0.003 & & & 0.034 & & & 0.128 \\
\hline & & & $(0.072)$ & & & $(0.175)$ & & & $(0.177)$ \\
\hline HH p.c. expend. $\times$ rank & & & $-0.769 *$ & & & -0.396 & & & $-1.513^{* *}$ \\
\hline$\times$ election & & & $(0.465)$ & & & $(0.524)$ & & & $(0.687)$ \\
\hline Time to village office (\%) & & & 0.171 & & & 0.080 & & & 0.158 \\
\hline xrank & & & $(0.122)$ & & & $(0.236)$ & & & $(0.347)$ \\
\hline \multirow{2}{*}{$\begin{array}{l}\text { Time to village office }(\%) \times \\
\text { rank } \times \text { election }\end{array}$} & & & -0.043 & & & -0.155 & & & 0.780 \\
\hline & & & $(0.610)$ & & & $(0.727)$ & & & $(0.784)$ \\
\hline Hamlet poverty score (\%) & & & 0.247 & & & 0.018 & & & $0.470 *$ \\
\hline$\times$ rank & & & $(0.175)$ & & & $(0.270)$ & & & $(0.267)$ \\
\hline Hamlet poverty score (\%) & & & 0.064 & & & 0.383 & & & -0.285 \\
\hline$\times$ rank $\times$ election & & & $(0.308)$ & & & $(0.348)$ & & & $(0.437)$ \\
\hline \multirow[t]{2}{*}{ Minority $\mathrm{HH} \times$ rank } & & & -0.152 & & & 0.127 & & & $-0.614^{* *}$ \\
\hline & & & $(0.206)$ & & & $(0.303)$ & & & $(0.307)$ \\
\hline Minority hh $\times$ rank & & & 0.085 & & & -0.088 & & & 0.358 \\
\hline$\times$ election & & & $(0.328)$ & & & $(0.406)$ & & & $(0.488)$ \\
\hline Project type fixed effects & YES & YES & YES & YES & YES & YES & YES & YES & YES \\
\hline Rank $\times$ phase controls & YES & YES & YES & YES & YES & YES & YES & YES & YES \\
\hline Sample & HH only & HH, Elite & HH only & HH only & HH, Elite & HH only & HH only & HH, Elite & HH only \\
\hline Observations & 965 & 2190 & 819 & 420 & 961 & 343 & 560 & 1295 & 491 \\
\hline $\begin{array}{l}\text { P-value from joint test of } \\
\text { rank * election interactions }\end{array}$ & & & 0.150 & & & 0.830 & & & 0.000 \\
\hline
\end{tabular}

Notes: Results from conditional fixed-effects logit regression, where each observation is a project type for a particular respondent in the household and / or elite survey. Robust standard errors in parentheses, adjusted for clustering at the village level. The dependent variable is a dummy equal to 1 if the respective project type was chosen by the village. In columns 1, 3, 4, 6, 7, and 9, the sample includes household respondents and in columns 2 , 5 , and 8, it includes both household and elite respondents (village heads, village parliament heads, and hamlet heads). The individual's most preferred project receives a rank of 1 . Phase is a dummy variable equal to 1 if the village's treatment was assigned during Phase I. Male is a dummy equal to 1 if the respondent is male, HH p.c. expend. gives estimated household per capita expenditure, time to village office gives time from the respondent's hamlet to the village office and is measured as a percentile among hamlets within the village, poverty score is a ranking of hamlets by poverty and is measured as a percentile, and minority household is a dummy equal to one if the household is a minority in its village, Relatively central hamlets and relatively wealthy hamlets correspond to low percentiles. The $\mathrm{p}$-value is from a $\mathrm{Chi}^{2}$ test of the joint significance of the election rank interactions. The conditioning variable is respondent $\times$ general/women's project in columns 1 through 3 , and respondent in columns 4 through 9. * significant at $10 \%$; ** significant at $5 \%$; *** significant at $1 \%$. 
Table 6: Impact of Plebiscites on Project Location

\begin{tabular}{|c|c|c|c|}
\hline & (1) & (2) & (3) \\
\hline & Whole Sample & General & Women's \\
\hline \multirow[t]{2}{*}{ Hamlet affluence (\%) } & -1.048 & $-3.104 * * *$ & 1.052 \\
\hline & $(0.654)$ & $(1.147)$ & $(0.894)$ \\
\hline \multirow[t]{2}{*}{ Hamlet affluence $(\%) \times$ election } & $-2.357 *$ & -2.333 & $-5.386 * *$ \\
\hline & $(1.276)$ & $(2.229)$ & $(2.210)$ \\
\hline \multirow[t]{2}{*}{ Hamlet population share } & 2.414 & $8.064 * *$ & -2.568 \\
\hline & $(2.077)$ & $(3.855)$ & $(2.972)$ \\
\hline \multirow[t]{2}{*}{ Population share $\times$ election } & $-8.478 *$ & $-16.217^{*}$ & 2.484 \\
\hline & $(5.092)$ & $(8.454)$ & (7.319) \\
\hline \multirow[t]{2}{*}{ Time to village office (\%) } & 0.626 & 1.665 & -0.087 \\
\hline & $(0.665)$ & $(1.152)$ & $(0.977)$ \\
\hline \multirow[t]{2}{*}{ Time to vill. office $(\%) \times$ elect } & $-3.460 * *$ & $-6.365 * *$ & -1.346 \\
\hline & $(1.508)$ & $(2.627)$ & $(1.965)$ \\
\hline \multirow[t]{2}{*}{ Minority hamlet } & -0.835 & -0.450 & \\
\hline & $(0.917)$ & $(1.445)$ & \\
\hline \multirow[t]{2}{*}{ Minority hamlet $\times$ election } & 1.042 & -1.420 & \\
\hline & (1.327) & (1.657) & \\
\hline $\begin{array}{l}\text { Hamlet characteristic } \times \\
\text { phase fixed effects }\end{array}$ & YES & YES & YES \\
\hline Observations & 318 & 172 & 158 \\
\hline $\begin{array}{l}\text { P-value from joint test of } \\
\text { election interactions }\end{array}$ & 0.10 & 0.13 & 0.11 \\
\hline
\end{tabular}

Notes: Results are from conditional fixed-effects logit regression. Robust standard errors in parentheses, adjusted for clustering at the village level. The hamlet affluence measure is the village head's ranking of hamlets in his village by poverty. Population share gives the hamlet's share of village population. A high percentile corresponds to relatively affluent hamlets and distant hamlets. Phase is a dummy variable equal to 1 if the village's treatment was assigned during Phase II (i.e., the village is located in Southeast Sulawesi). The p-value gives the/joint significance of the hamlet characteristic*election interactions. The conditioning variable is village $\times$ general/women's project in column 1 and village in columns 2 and 3. * significant at 10\%; ** significant at 5\%; *** significant at $1 \%$. 
Table 7: Impact of Plebiscites on Perceptions of KDP process

\begin{tabular}{llllllc}
\hline & $(1)$ & \multicolumn{2}{c}{$\begin{array}{c}(2) \\
\text { General }\end{array}$} & $\begin{array}{c}(3) \\
\text { Project }\end{array}$ & \multicolumn{2}{c}{$\begin{array}{c}\text { Women's Project } \\
\text { Women }\end{array}$} \\
\hline & Pooled & Men & Women & \multicolumn{2}{c}{ Men } & Women \\
\hline Questions & & & & & \\
Was the project chosen in accordance with & $0.464^{* *}$ & $1.031^{* * *}$ & $0.667^{* *}$ & 0.159 & $0.754^{* *}$ \\
your wishes? & $(0.188)$ & $(0.311)$ & $(0.329)$ & $(0.303)$ & $(0.335)$ \\
Will the proposal benefit you personally? & $0.484^{* *}$ & $0.587^{*}$ & $1.069^{* * *}$ & 0.180 & 0.383 \\
& $(0.191)$ & $(0.319)$ & $(0.298)$ & $(0.255)$ & $(0.312)$ \\
Will you use the project? & $0.970^{* *}$ & 0.809 &. & 0.794 & $1.003^{*}$ \\
& $(0.381)$ & $(0.644)$ &. & $(0.638)$ & $(0.557)$ \\
Was the chosen proposal fair? & $0.431^{* *}$ & $0.756^{* * *}$ & $0.833^{* * *}$ & 0.102 & $0.636^{* *}$ \\
& $(0.186)$ & $(0.265)$ & $(0.321)$ & $(0.287)$ & $(0.287)$ \\
Is the chosen proposal in accordance with & $0.405^{* *}$ & $0.605^{* *}$ & $0.932^{* * *}$ & 0.091 & 0.534 \\
the people's aspirations? & $(0.189)$ & $(0.256)$ & $(0.282)$ & $(0.282)$ & $(0.367)$ \\
Are you satisfied with KDP? & $0.625^{* *}$ & $0.691^{* *}$ & $0.528^{*}$ &. &. \\
(not project specific) & $(0.263)$ & $(0.271)$ & $(0.314)$ &. &. \\
& & & & & \\
\hline
\end{tabular}

Notes: Each cell is the coefficient on the plebiscite dummy from a different regression. All questions except 'will you use the project' are multiple-ordered response questions estimated using ordered probit models; 'will you use the project' is a binary response question estimated using a probit model. Robust standard errors in parentheses, adjusted for clustering at the village level. In column 1, the sample includes both the general and women's proposals, whereas in column 2 it is limited to the general proposal and in column 3 to the women's proposal. All dependent variables are 0/1 dummies, with the higher outcome (more satisfied, fairer, etc) receiving a score of 1 . All regressions include phase fixed effects and controls for gender, age, log per capita expenditure, number of household members, and occupation. Cells indicated with a '.' could not be estimated as the elections variable perfectly predicts the outcome.

* significant at $10 \%$; $* *$ significant at $5 \%$; ${ }^{* *}$ significant at $1 \%$. 
Table 8: Impact of plebiscites on KDP voluntary contributions

\begin{tabular}{lccccc}
\hline & $(1)$ & \multicolumn{2}{c}{$\begin{array}{c}(2) \\
\text { General Project }\end{array}$} & $\begin{array}{c}(4) \\
\text { Women's Project }\end{array}$ \\
\hline & \multicolumn{7}{c}{ Pooled } & Men & Women & Men & Women \\
\hline If the project happens, will you contribute...? & & & & & \\
Labor & $0.164^{* *}$ & $0.207^{*}$ & $0.271^{* * *}$ & 0.127 & 0.087 \\
& $(0.062)$ & $(0.079)$ & $(0.088)$ & $(0.077)$ & $(0.100)$ \\
Money & $-0.043^{*}$ & $-0.104^{*}$ & -0.002 &. & -0.02 \\
& $(0.021)$ & $(0.047)$ & $(0.017)$ &. & $(0.019)$ \\
Anything & $0.178^{* * *}$ & $0.192^{*}$ & $0.304^{* * *}$ & 0.116 & 0.145 \\
& $(0.055)$ & $(0.075)$ & $(0.073)$ & $(0.072)$ & $(0.084)$ \\
& & & & & \\
\hline
\end{tabular}

Notes: Each cell is the marginal effect of the plebiscite dummy from a different probit regression. Robust standard errors in parentheses, adjusted for clustering at the village level. Dependent variables are 0/1 dummies, with "yes" receiving a score of 1 and "no" a score of 0 . All regressions contain phase fixed effects and controls for gender, age, log per capita expenditure, number of household members, and occupation. See also Notes to Table 7.

* significant at $10 \%$; $* *$ significant at $5 \%$; *** significant at $1 \%$.

Table 9: Impact of plebiscites on knowledge and dialog

\begin{tabular}{lccc}
\hline & \multicolumn{1}{c}{$(1)$} & & \\
\hline Knowledge: & Pooled & Men & Women \\
Did the respondent correctly identify the type and location of the & $0.218^{*}$ & $0.212^{*}$ & $0.255^{*}$ \\
selected general proposal? & $(0.108)$ & $(0.109)$ & $(0.148)$ \\
Did the respondent correctly identify the type and location of the & $0.288^{* * *}$ & $0.240^{* *}$ & $0.370^{* * *}$ \\
selected women's proposal? & $(0.086)$ & $(0.089)$ & $(0.126)$ \\
& & & \\
Discussions: & -0.013 &. & -0.132 \\
Did you discuss development issues with anyone? & $(0.031)$ &. & $(0.147)$ \\
& 0.015 & 0.039 & -0.121 \\
Did you discuss development issues with any household & $(0.076)$ & $(0.059)$ & $(0.147)$ \\
members? & -0.003 & -0.011 & -0.039 \\
Did you discuss development issues with anyone in government? & $(0.078)$ & $(0.130)$ & $(0.075)$ \\
& & & \\
\hline
\end{tabular}

Notes: See Notes to Tables 7 and 8.

* significant at $10 \%$; $* *$ significant at $5 \%$; *** significant at $1 \%$. 
Figure 1: Project Type Selected

\section{Project Type}
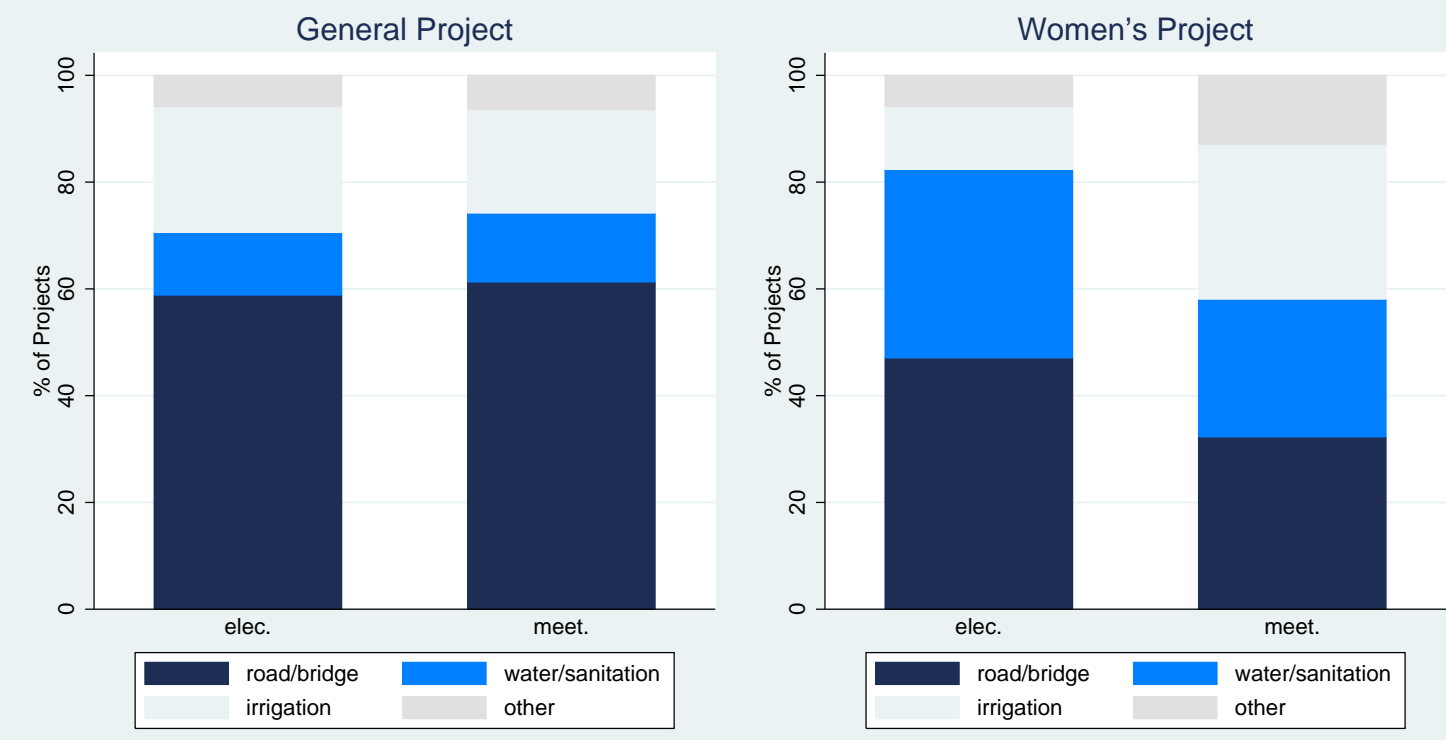

Figure 2: Plebiscites and Project Location, by Hamlet Poverty Rank

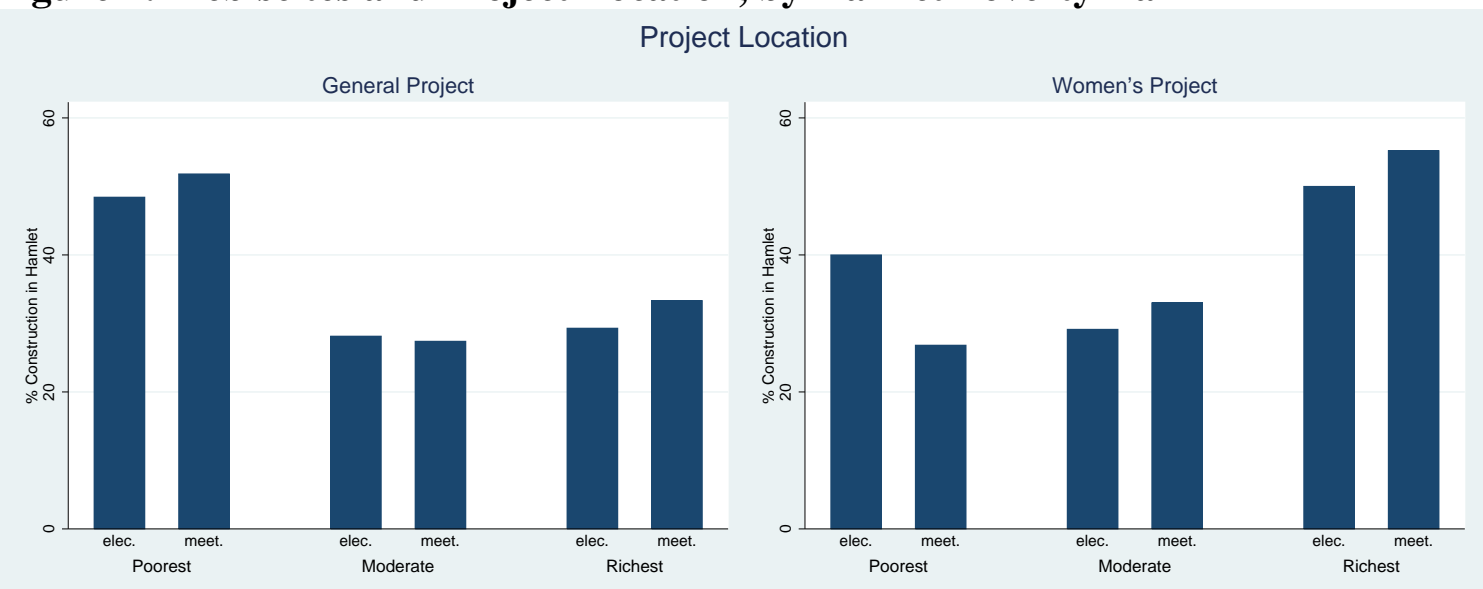

Notes: Poorest refers to the poorest hamlet in the village, richest to the wealthiest hamlet, and moderate to the hamlets in between, where hamlet affluence is ranked subjectively by the village head. 
Figure 3: Plebiscites and Project Location, by Hamlet Population

Project Location
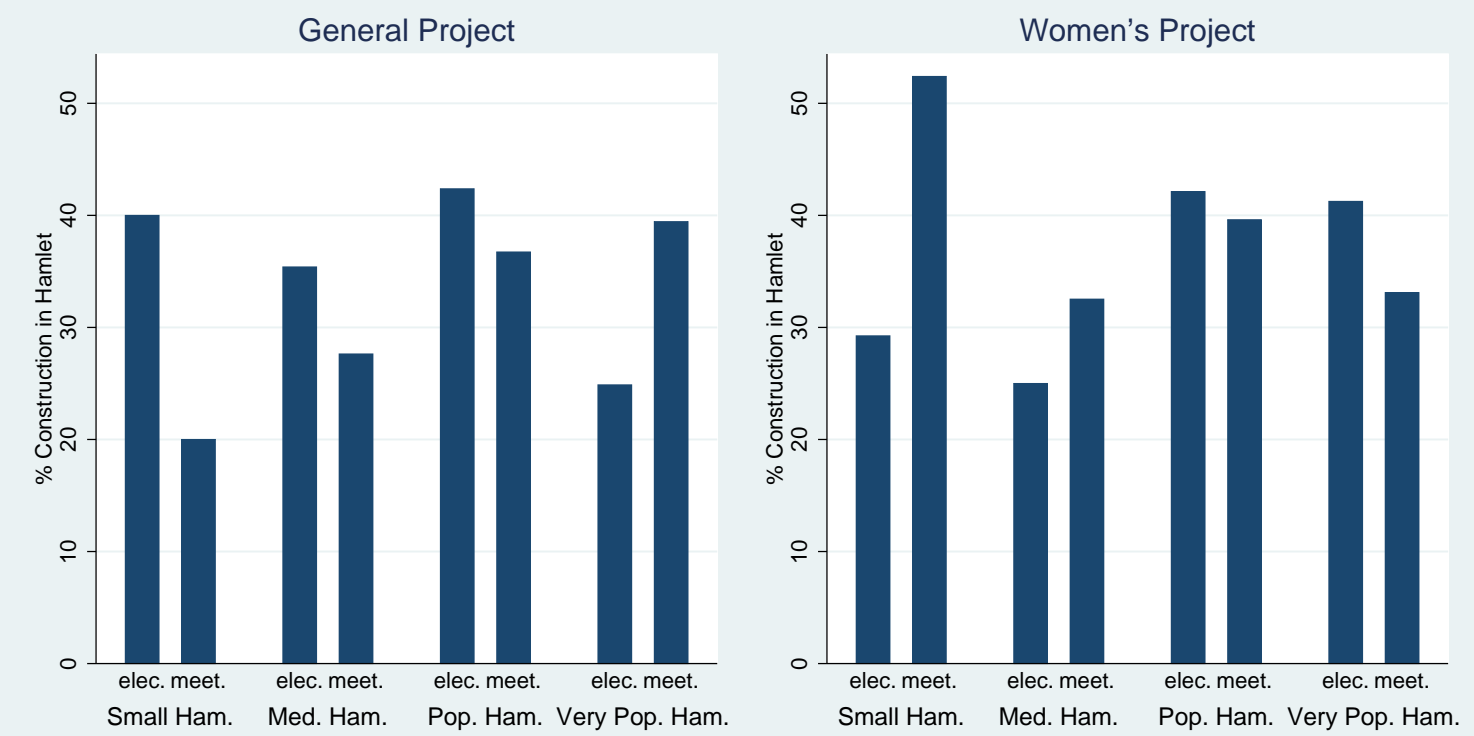

Figure 4: Plebiscites and Project Location, by Hamlet Centrality

Project Location
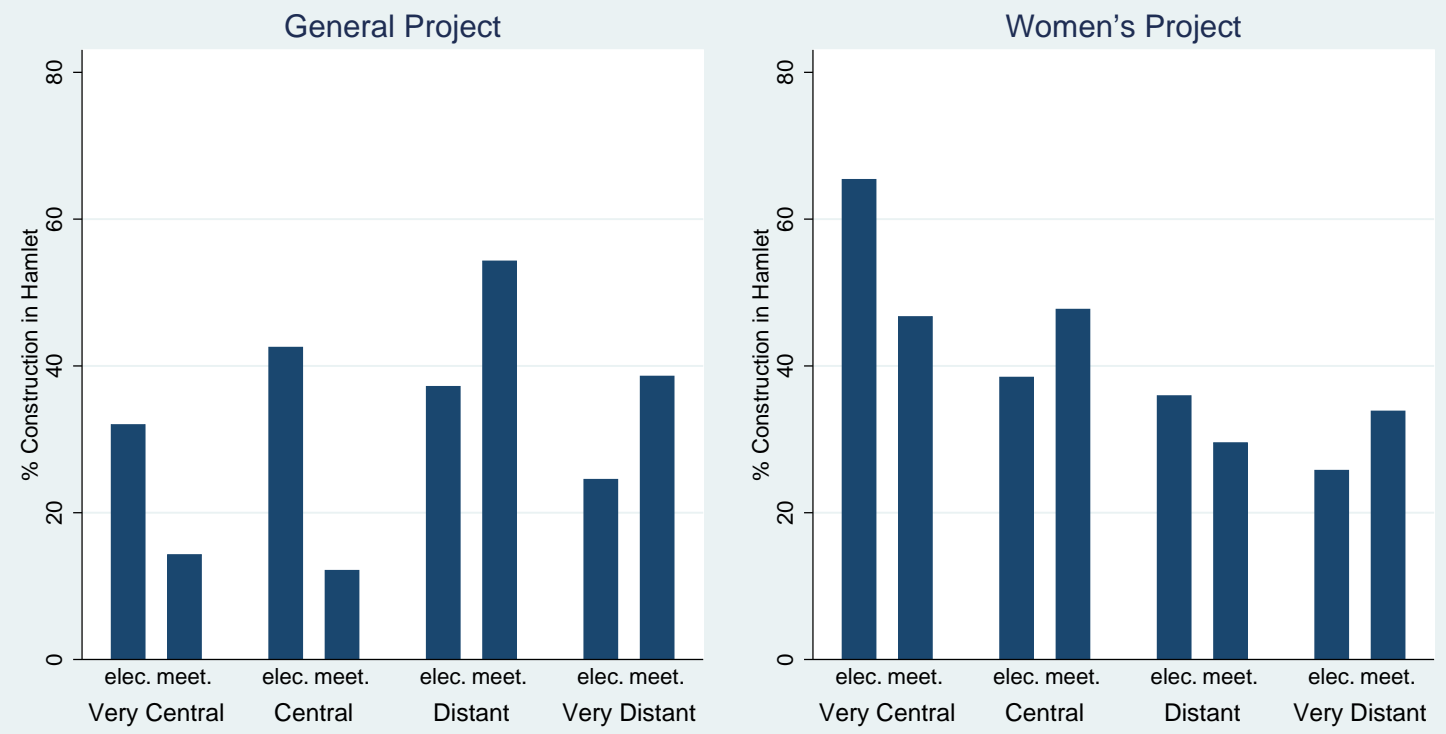